\title{
BREASTFEEDING: MOTHERS AND HEALTH PRACTITIONERS IN THE CONTEXT OF PRIVATE MEDICAL CARE IN GAUTENG
}

Author:

Diana du Plessis ${ }^{1}$

\section{Affiliation:}

${ }^{1}$ Department of Nursing Science, University of Johannesburg, South Africa

\section{Correspondence to:}

Diana du Plessis

e-mail:

dianadp@uj.ac.za

\section{Postal address:}

University of

Johannesburg, PO Box

524, Auckland Park, 2006,

Johannesburg, South

Africa

\section{Keywords:}

breastfeeding; Gauteng province; South Africa; paediatric nutrition; postnatal care

\section{Dates:}

Received: 15 May 2008 Accepted: 09 Dec. 2008 Published: 29 June 2009

How to cite this article: Du Plessis, D., 2009, 'Breastfeeding: Mothers and health practitioners, in the context of private medical care in Gauteng', Health SA Gesondheid Art. \#437, 10 pages. DOI: 10.4102/hsag.v14i1.437

\section{This article is available} at:

www.hsag.co.za

\section{(c) 2009. The Authors.}

Licensee: OpenJournals Publishing. This work is licensed under the Creative Commons Attribution License.

\begin{abstract}
Despite the well-documented health benefits of breastfeeding and recommendations by the Department of Health for women to exclusively breastfeed for approximately the first six months of life and continuation beyond one year, a large percentage of South African women do not breastfeed their infants, or only do so for a short period of time. No national South African statistics are available but figures emerging from the attendance of mothers at a baby clinic on the West Rand in Gauteng indicated the following: $64 \%$ of the mothers breastfeed up to six weeks, after which the figure rapidly declines to less than $20 \%$ at three months (Truter 2007). Several studies have assessed the attitudes of health care personnel towards breastfeeding, but little is known of the type of information given to breastfeeding mothers by private medical practitioners who are the frontline of contact with clients and who may convey information that either promotes or discourages breastfeeding. The following question was thus formulated: With regard to breastfeeding, what are the constraints to breastfeeding in private practice?
\end{abstract}

Therefore, in order to understand the constraints to breastfeeding, the purpose of this study was to assess the breastfeeding information given to pregnant women by health professionals in private practice. The specific objectives of the study were to determine the breastfeeding recommendations made by private health professionals during pregnancy, to describe the management of breastfeeding in the consulting rooms of private medical practitioners, and to describe women's experiences of breastfeeding in private hospitals. In Phase 1 of the study the population comprised all mothers who attended a support group for new mothers at a private post-natal clinic In Phase 2 the population comprised all mothers who attended a community baby clinic or support group. The sample consisted of all primigravidae who breastfed or attempted to breastfeed in the first six weeks.

Purposive convenient sampling, as described by Babbie and Mouton (2002:166), was used in both phases of the study. All participants chose a gynaecologist as the primary care giver and delivered in various private hospitals in Johannesburg. Data were collected by means of an anonymous questionnaire, compiled from national and international literature, as well as personal interviews. Data from the questionnaires were analysed by hand. Descriptive statistics were applied. The interviews were analysed according to the descriptive analysis suggested by Tesch (in Creswell, 1994:155). Themes that emerged were clustered and coded. A co-coder, experienced in the field of qualitative research, assisted with the analysis of the transcripts of the interviews. A literature control was conducted to validate the findings. Ethical considerations were based on the DENOSA Ethical Standards for Nurse Researchers (1998:2.3.2-2.3.4). Themes and sub-themes were identified.

\section{OPSOMMING}

Ten spyte van die goed gedokumenteerde gesondheidsvoordele van borsvoeding en die aanbevelings van die Departement van Gesondheid dat vroue vir ongeveer die eerste ses weke tot een jaar uitsluitlik moet borsvoed, word gevind dat 'n groot aantal Suid-Afrikaanse vroue hul babas nie borsvoed nie, of slegs vir 'n kort tydperk borsvoed. Geen nasionale Suid-Afrikaanse statistiek is beskikbaar nie, maar $64 \%$ van moeders wat 'n babakliniek besoek het op die Wes Rand in Gauteng borsvoed steeds op ses weke, waarna die aantal borsvoedende moeders verminder tot minder as $20 \%$ op drie maande (Truter 2007). Verskeie studies het die houding van gesondheidspersoneel ten opsigte van borsvoeding bepaal, maar min is bekend oor die tipe inligting wat deur die mediese praktisyn aangebied word. Hierdie praktisyn het eerstehandse kontak met die kliente en mag inligting aanbied wat borsvoeding kan bevorder of belemmer. Die volgende vraag is dus geformuleer: Met betrekking tot borsvoeding, wat is die beperkinge in privaat praktyk?

Die doel van hierdie studie was om vas te stel watter borsvoedinginligting deur gesondheidspersoneel in privaatpraktyk aan swanger vroue oorgedra word. Die doelwitte van die studie was om die aanbevelings om te borsvoed te bepaal, om die behandeling en sorg in die spreekkamer van die geneesheer te beraam, en om die vroue se belewenisse van borsvoeding in privaat hospitale te ondersoek. In Fase 1 van die studie het die populasie bestaan uit alle moeders wat 'n ondersteuningsgroep by 'n privaat nageboortekliniek bygewoon het. In Fase 2 was die populasie alle moeders wat 'n ondersteuningsgroep bygewoon het en 'n babakliniek besoek het. Die steekproef het bestaan uit alle primigravidae wat borsvoed of probeer het om te borsvoed gedurende die eerste ses weke. Doelgerigte gerieflikheidssteekproef neming, soos beskryf deur Babbie and Mouton (2002:166), is in albei fases van die studie gebruik. Alle deelnemers het 'n ginekoloog as primêre sorggewer gebruik en het in verskillende Johannesburgse hospitale gekraam. Data is deur middel van anonieme vraelyste, saamgestel uit nasionale en internasionale literatuur, ingesamel sowel as deur middel van persoonlike onderhoude. Data vanaf die vraelyste is deur die navorser ontleed en beskrywende statistiek is toegepas. Die onderhoude is ontleed volgens die beskrywende analise voorgestel deur Tesch (in Creswell, 1994:155). Temas is saamgevoeg en gekodeer.'n Mede-kodeerder was behulpsaam met die ontleding van die transkripsies van die onderhoude. Literatuur is aangewend as kontrole om die bevindinge te valideer. Etiese oorwegings is gebaseer op die DENOSA Etiese Standaarde vir Verpleegnavorsers (1998:2.3.2-2.3.4). Temas en subtemas is geïdentifiseer. 


\section{INTRODUCTION AND BACKGROUND}

Breastfeeding is preferred for all infants, and exclusive breastfeeding is recommended for the first six months after birth. The importance and benefits of breastfeeding to both mother and infant are well known and documented. Exclusive breastfeeding for the first six months of life offers important benefits on the infant and the mother: superior nutritional content, enhanced immunological status of the newborn, strengthening of the mother-infant relationship, delayed ovulation and economic savings (Hillenbrand \& Larsen 2002:e59). It protects infants against common childhood diseases like gastrointestinal infections, otitis media and pneumonia, and hence against some of the major causes of childhood mortality. The promotion, protection and support of breastfeeding is an exceptionally cost-effective strategy for the prevention of childhood disease, particularly in developing countries. Early initiation of breastfeeding and exclusive breastfeeding until six months not only influences survival after the first month of life but also has a direct impact on the health of the newborn (Bhutta et al. 2005:519-617).

UNICEF issued the following key messages regarding breastfeeding in 2002 (WHO 2003:1):

- Breast milk alone is the only food and drink an infant needs for the first six months. No other food or drink, not even water, is usually needed during this period.

- Breastfeeding should be initiated within one hour of birth.

- Almost every mother is physically able to breastfeed successfully.

- Newborn babies should be kept close to their mothers because it creates a special bond between mother and child.

- Frequent breastfeeding causes more milk to be produced.

- Bottle-feeding can lead to illness and death. If a woman cannot breastfeed her infant, the baby should be fed breast milk or a breast milk substitute from an ordinary clean cup.

Despite the well-documented health benefits of breastfeeding and recommendations by the Department of Health for women to exclusively breastfeed for approximately the first six months of life and continuation beyond one year, a large percentage of South African women do not breastfeed their infants, or do so for only a short period of time (WHO/UNICEF 2006:29). This correlates with large-scale national surveys in the United States of America (USA) that found that despite efforts to increase breastfeeding in the USA, only $59 \%$ of women initiated breastfeeding, with lower rates seen in mothers who are black, young, less educated and in the lowest income groups (Taveras et al. 2004:e283-e290).

In sub-Saharan Africa, only $30 \%$ of babies less than six months of age are exclusively breastfed and only about $42 \%$ of mothers begin breastfeeding within one hour of birth (WHO/UNICEF, 2006:29). No national South African statistics are available but attendance of mothers at a baby clinic on the West Rand in Gauteng indicated the following: $64 \%$ of the mothers breastfed up to six weeks, after which the number rapidly declined to less than $20 \%$ at three months (Truter 2007).

In South Africa, the pregnant woman who subscribes to a medical aid scheme usually consults a medical practitioner for antenatal care and relies on him/her to guide and counsel her during the pregnancy, birth and the post-natal period (Fraser, Cooper \& Nolte 2006:39)

In order to be consistent with the health goals of the Department of Health, medical practitioners providing antenatal care should encourage breastfeeding whenever possible. The parents' choice to breast or bottle feed their infant is the consequence of a complex decision and the medical practitioner's role is to provide information objectively so that the parents' decision can be made on an informed and factual basis. The advice given by this medical practitioner is often seen as the most influential, as the woman sees him as the leader of the health team (Du Plessis 1992:27; Hillenbrand \& Larsen 2002:59). In 2002 Du Plessis conducted a survey on the information given by private medical practitioners to pregnant and lactating mothers and found that medical practitioners did not educate, assist, manage or refer women who wanted to breastfeed (Du Plessis 2002).

The mother who consults a private medical practitioner usually delivers her baby in a private hospital under his/her supervision. Due to the escalating cost of health care she is discharged on the third day in the absence of any complications after a vaginal delivery. If she has a Caesarean section she is then discharged on the fourth day, often before lactation is established. If the baby was admitted to the Neonatal Intensive Care Unit (NICU) the mother is often not supported, accompanied or guided to breastfeed. Throughout the post-natal period the mother rarely has contact with health care providers unless she seeks help herself, and she often has to rely on telephonic discussions with the medical practitioner, receptionist or maternity ward staff when she encounters problems with breastfeeding.

Much has been learned with regard to effective interventions during the past decades. It is clear that mothers need support to initiate and sustain optimal breastfeeding especially within the first days and weeks after birth. Is is especially during those first few days that doubts arise and breastfeeding problems occur, which can discourage a mother. Although optimal breastfeeding is one of the most achievable essential nutrition actions, many studies have found infant feeding to be the aspect that most women are concerned with in the post-natal period. Although many women express the need to breastfeed, and after the experience would relate how much they enjoyed it, it appears as if few mothers in South Africa regard themselves to be successful with their breastfeeding attempts. When mothers fail with their breastfeeding attempts they experience feelings of loss and regret. Odendaal (2003:103) argues that this could interfere with the fostering of a long-term relationship between mother and baby.

\section{LITERATURE REVIEW}

Throughout most of the 20th century, initiation and duration of breastfeeding declined worldwide, as a result of rapid social and economic change, urbanisation and marketing of breast milk substitutes. In recent years the global trend has shifted towards improved breastfeeding practices (WHO/UNICEF, 2003). However, the prevalence of exclusive breastfeeding and other optimal infant feeding practices is still low in many countries. In many developing countries certain cultural beliefs and outdated hospital practices continue to interfere with optimal breastfeeding.

To be declared baby-friendly, a facility or hospital must implement these ten steps for successful breastfeeding:

1. Have a written breastfeeding policy that is routinely communicated to all health care staff

2. Train all health care staff in the skills necessary to implement this policy

3. Inform all pregnant women about the benefits and management of breastfeeding

4. Help mothers to initiate breastfeeding within one half-hour of birth

5. Show mothers how to breastfeed and maintain lactation, even if they should be separated from their infants

6. Give newborn infants no food or drink other than breast milk, unless medically indicated

7. Practice rooming in - that is, allow mothers and infants to remain together 24-hours a day

8. Encourage breastfeeding on demand

9. Give no artificial teats or pacifiers to breastfeeding infants

10. Foster the establishment of breastfeeding support groups, and refer mothers to them on discharge from the hospital or clinic 
The Baby-Friendly-Hospital Initiative, supported by WHO and UNICEF, was launched in 1991. This initiative has made a significant impact on breastfeeding practices globally through implementation of the 'Ten Steps to Successful Breastfeeding', focusing on maternity services and newborn care. A maternity facility can be certified as 'baby-friendly' if it adheres to the steps tabulated in Box 1. Step 3 places emphasis on antenatal care and Step 5 involves breastfeeding guidance. In Step 10 the focus is on the establishment of breastfeeding support groups after discharge from the hospital.

Previous reports have demonstrated that support by health care providers, and in particular physician, can improve rates of breastfeeding initiation and duration. However, a survey of more than a thousand active fellows of the American Academy of Pediatrics, carried out by Schanler, $\mathrm{O}^{\prime}$ Connor and Lawrence (1999:e35), revealed that only $65 \%$ recommended exclusive breastfeeding for the first month of life and only $37 \%$ recommended breastfeeding for one year.

It is unclear whether residence training for paediatricians, obstetricians/gynaecologists and family physicians provides the knowledge and skills necessary for effective breastfeeding promotion. Freed et al. (1995:273:472-476) surveyed a random sample of practicing physicians and residents and found that all of the groups demonstrated significant knowledge deficits in the benefits and clinical management of breastfeeding. In professional development programmes for medical practitioners the technique of breastfeeding and management of common breastfeeding problems seems to be overshadowed by research on HIV transmission and clinical trails. According to Howard, Schaffer and Lawrence (1997:24:240-246) health practitioners have limited knowledge of breastfeeding and mothers are not informed on infant nutritional choices. The result is that mothers do not receive adequate knowledge and support to breastfeed; they do not understand the physiology of breastfeeding and are not taught the basic technique of breastfeeding.

In a study conducted by Schanler et al. (1999:e35) paediatricians were found to be of the opinion that breastfeeding and formula feeding are equally acceptable methods for feeding infants. Whenever the mother experiences a problem she would then change to a supplement. Health providers are not aware of the benefits of exclusive breastfeeding and doubt that breast milk alone can nourish a baby (Myburgh, 2003:16). The majority of paediatricians are unfamiliar with the contents of the BabyFriendly-Hospital Initiative and had not attended a presentation on breastfeeding management in the previous three years.

In a study carried out by Kieffer et al. (1997:1313-1116) it was found that medical practitioners are reportedly very influential in mothers' decisions regarding infant feeding. This finding is reiterated by Sharret-Stevens (2002:4-5) who is of the opinion that the knowledge and attitudes of health care practitioners are instrumental in the mother's decision to breastfeed.

Harmful hospital practices that undermine the new mother's breastfeeding attempts are well described, and include hospital policies and rules that undermine the mother's choice for exclusive breastfeeding, in order to streamline hospital routine. Examples of these practices include four-hourly feeds with a time restriction instead of demand feeding, thus interfering with the individual nature of breastfeeding and the emphasis on correction of hypoglycemia of the newborn by means of a supplement. This has serious consequences for the baby, as the protective IgA in colostrum is needed to strengthen the gastrointestinal system of the baby for the permeability of the MI virus.

Other harmful practices include separation of the mother and child after delivery instead of rooming-in, and the fact that lactation consultants or experts on breastfeeding are not always available or appointed to assist the mother with her breastfeeding efforts. In the hospital many women receive sleeping tablets and many maternity staff members supplement the baby with formula feeds every four hours. The mother is thus not used to the fact that the baby feeds more often during the night. This behaviour disturbs the mother, who would then telephone the hospital staff to ask for advice - only to then receive advice that usually included the recommendation of supplementary feeding.

Inconsistencies and deficits in the knowledge of nurses and midwives who work in maternity settings have been well researched. In a study of the attitudes and knowledge of dieticians, nurses and physicians it was noted that dieticians scored higher marks than nurses on the knowledge items. Attitudes in all the groups were positive toward breastfeeding but knowledge and attitude scores were only weakly related (Hayes 1981:430-433). Segeel and Du Plessis (2006:69) found that midwives and nurses often give conflicting and outdated advice. In this study it was found that the staff in maternity units were not regarded as breastfeeding experts by the patients. The lack of well-trained staff within the hospital environment furthermore reduces the time that health personnel can spend at the patients' bedsides, and the utilisation of agency staff that are not necessarily equipped to help the mothers in the post-natal ward increases the problem.

Segeel and Du Plessis (2006:69) are of the opinion that many problems regarding breastfeeding can be corrected or managed during the first ten days post-partum by means of effective education and support. If the spouse or partner is uneducated or ill-informed with regard to breastfeeding then the mother's support system fails, as her own mother is often not available, or was possibly unsuccessful in her own breastfeeding attempts (Myburg, 2003:173). Whenever the mother would experience problems during the post-natal period it would be contributed to 'weak, not nutritious enough, too little milk'. Many women are led to believe that they do not have enough colostrum or that the bluish appearance of the mature milk is too weak to sustain the infant.

Many women express a lack of knowledge regarding the volume of breast milk and are generally concerned about the amount of milk the baby receives. The fact that she cannot see the amount of breast milk the baby consumes leads her to believe that her milk supply is insufficient to sustain the baby. When the baby goes through a growth spurt she would again assume the milk is not sufficiently nutritious. Poor knowledge on the physiology of lactation leads the mother to believe that she is not producing enough milk. If the baby thus goes through a growth spurt or does not adhere to 'hours' then she is of the opinion that the milk supply is insufficient and that a supplementary feeding is necessary. The result is that the mother then provides breast milk substitutes, which in turn reduces her own milk supply.

There are numerous variables that interact and account for a successful breastfeeding experience. Social support for optimal breastfeeding can take many forms: acceptance, encouragement, timely and salient information regarding breastfeeding, and practical skills to overcome socio-economic, cultural or biomedical obstacles to optimal breastfeeding. Furthermore, mothers are discharged from hospital soon after giving birth because of medical aid insistence (Segeel \& Du Plessis 2006:68), often before lactation is established. Many women who had Caesarean sections suffer from pain, discomfort and fatigue, and are thus advised to make use of a supplement during the night in order to be able to rest, which in turn affects breastfeeding negatively.

\section{PROBLEM STATEMENT}

Infant and young child feeding practices worldwide are not optimal. Global monitoring indicates that only $39 \%$ of all infants worldwide are exclusively breastfed, even when the assessment 
is made in children less than 4 months of age (WHO 2005:vii). In South Africa the promotion and support of breastfeeding has emerged as a public health priority in recent years Scientific evidence has guided the development of international recommendations for optimal infant feeding practices, which include exclusive breastfeeding for six months. These recommendations were adopted following a systematic review of current scientific evidence on the optimal duration of exclusive breastfeeding.

After decades of research on breastfeeding, new evidence points to an even greater effectiveness of breastfeeding for saving lives and improving health. Despite national efforts to promote breastfeeding for the first six months after childbirth, and despite mothers' intentions to breastfeed exclusively (Du Plessis 2002), sub-optimal practices put babies at risk. By the end of the first week many mothers provide babies with water or formula to supplement breast milk. It appears that in spite of policies to promote breastfeeding, for many women access to sensible breastfeeding advice and emotional support for exclusive and extended breastfeeding is difficult to come by. This is especially true in the private hospital context, where policy makers and programme managers underestimate the importance of breastfeeding.

Successful breastfeeding depends in part on the support of the staff directly involved with the breastfeeding mothers, and most women report that health care providers are their primary source of information on infant feeding. They should therefore be trained and equipped to support maternal efforts to breastfeed. This is often not the case: breastfeeding information is not given during the antenatal visit to the private medical practitioner and health care providers are often not competent in lactation management and counselling skills. Although the private hospitals claim to be 'baby-friendly', the principles of the Baby-Friendly Hospital Initiative are not standard clinical practice and the midwives are not regularly updated. Furthermore, the study of Kieffer et al. (1997) revealed that physicians are reportedly very influential in mother's decisions regarding infant feeding. Kitzinger (2000:33) agrees with Freed et al. (1995:472), stating: 'whether a physician or a physician's wife has breastfed is the best predictor of a doctor's ability and willingness to give accurate advice and appropriate support to latching mothers'.

From the analysis of questionnaires collected at a busy childbirth education centre over a period of 2 years, $99.7 \%$ of women indicated their intention to breastfeed exclusively for 'as long as they possibly can' or at least for the first four months - the duration of their maternity leave (Du Plessis, 2002). However, many women have limited contact with health services after giving birth and the absence of home visits by midwives or referral to lactation consultants or clinic sisters during the postnatal period decrease the chances for successful breastfeeding.

Despite national efforts to promote breastfeeding for the first six months after childbirth, and despite mother's intentions to breastfeed exclusively, few of them succeed beyond six weeks of neonatal age. Many mothers demonstrate sub-optimal breastfeeding practices, and provide babies with water or formula to supplement breast milk. It appears that in spite of policies to promote breastfeeding, for many women access to sensible breastfeeding advice and emotional support for exclusive and extended breastfeeding is difficult to come by.

From unstructured observations and discussions with community practitioners it appears that women are confused regarding breastfeeding. They appear to be insecure and need support and guidance, and rely on their medical practitioners to help them. Du Plessis (1992:40) found that a mother would contact the medical practitioner first if she encountered problems, yet if the problems continued and the mother then consulted a lactation consultant she would recall outdated and seemingly confusing information.
Several studies have been conducted to assess the attitudes of health care personnel towards breastfeeding and it was concluded that their attitude towards the promotion of breastfeeding is positive, although little is known of the level of information given by private medical practitioners who are the frontline contact with clients and who may convey information that either promotes or discourages breastfeeding. The following question was thus formulated: With regard to breastfeeding, what are the constraints to breastfeeding in private practice?

\section{PURPOSE OF THE RESEARCH}

The lack of breastfeeding knowledge on the part of new mothers suggests a paucity of quality of breastfeeding services for these clients. Therefore, in order to understand the constraints to breastfeeding, the purpose of this study was to assess the breastfeeding information given to pregnant women by health professionals in private practice.

\section{OBJECTIVES OF THE STUDY}

The objectives of the study were to:

- determine the breastfeeding recommendations made by private health professionals during pregnancy;

- describe the management of breastfeeding in the consulting rooms of private medical practitioners, and

- describe women's experiences of breastfeeding in private hospitals.

\section{KEY CONCEPTS}

Health professional: For the purpose of this study, this term refers to a medical practitioner or nurse/midwife registered by the Health Professional or Nursing (SANC) Councils.

Medical practitioner in private practice: This term refers to a person who practices as a doctor, gynaecologist or family physician in a private (non-governmental) practice. This person renders medical care, and gives health education and advice to pregnant mothers during pregnancy, labour and after the birth. The confinement takes place in a private hospital.

Health education: This refers to all the relevant information given regarding breastfeeding, including the advantages and disadvantages, latching technique, management of breastfeeding difficulties, and weaning.

Mother/primigravida: This term refers to a woman who delivered for the first time, regardless of the method of delivery.

\section{RESEARCH DESIGN}

This study was descriptive in nature. The study assessed the breastfeeding information given to mothers in private antenatal care, in order to understand the constraints in private hospitals, Gauteng, South Africa. It was contextual in nature as the subjects for this research study were women who attended private practices (medical and hospitals) in a specific geographical area in Johannesburg during the antenatal period and who attended a specific community clinic for baby care.

\section{POPULATION AND SAMPLING}

In Phase 1 of the study the population comprised all mothers who attended a support group for new mothers at a private post-natal clinic from June 2005 to March 2006. This support group is advertised in the media and meets monthly. The organiser of this support group was contacted and requested to participate in the study. 55 questionnaires were distributed to first-time mothers (primigravidae) and all 55 participated. Only primigravidae were included in the study so that previous birthing and breastfeeding experiences could not influence the findings of this study. 
In Phase 2 the population comprised all mothers who attended a community baby clinic or support group from April 2006 to July 2006. The sample consisted of all primigravidae who breastfed or attempted to breastfeed in the first six weeks. 80 self-administered questionnaires were distributed to willing participants at their first contact and 69 questionnaires were received back. The information obtained in these questionnaires was validated by six in-depth individual interviews. The researcher hoped to add depth, and gain more knowledge of and insights into the mothers' experiences of breastfeeding during pregnancy, labour and birth during the interviews.

Purposive convenient sampling, as described by Babbie and Mouton (2002:166), was used in both phases of the study to ensure that the sampled population was composed of elements with specific attributes necessary for this study. The sample was first-time mothers (primigravidae) who chose a gynaecologist as the primary care giver and delivered in various private hospitals on the West Rand in Gauteng. All mothers who attended the support group (see Phase 1) or attended a community clinic after the birth of their babies were requested to participate in the study.

The community clinic was purposive and conveniently selected due to the fact that this clinic is the only independent private one, not affiliated to or situated on the premises of a particular hospital group. The registered community practitioner agreed to distribute the questionnaires. The researcher later collected the completed questionnaires.

\section{SELECTION CRITERIA}

- Only primigravidae were selected, regardless of the outcome of the delivery, marital status or attendance of childbirth education classes

- All participating mothers had to be six weeks postpartum, and participated voluntarily after informed consent was obtained

- The mothers chose a medical practitioner as a primary caregiver

- All participants had attempted breastfeeding for at least three weeks.

\section{DATA COLLECTION INSTRUMENT}

\section{Questionnaire}

A questionnaire was compiled by the researcher, in English, after consulting national and international literature. It included a checklist, closed-ended and open-ended questions. The content and validity of the instrument is grounded in the extensive literature triangulation from national and international sources.

In order to ensure intersubjective reliability the questionnaire was critically reviewed by a community nurse practitioner who is also trained as a lactation consultant, and a practicing midwife of a midwife obstetric unit who holds a Masters degree in midwifery. During this phase four participants were invited to identify problems in the formulation of the questions. Questions that appeared to be unclear were reformulated and language edited. The questionnaire comprised sections striving to obtain information relevant to recommendations and education during antenatal visits to breastfeed, the management of breastfeeding, breastfeeding problems during pregnancy and after the birth of the baby, hospital policies and advice given by maternity staff.

The questionnaire included biographical detail, namely: mother's age, attendance of antenatal classes, whether she was still breastfeeding, and the sex of the medical practitioner or paediatrician. This last item was included as the researcher wanted to determine whether female practitioners gave similar information to their male counterparts. The participant had to indicate, on a checklist, the content and type of information she received during the pregnancy, labour and the post-natal period, and she had to identify the sources of information. If a respondent did not understand or answer a question she could indicate her response on the checklist as 'Don't know'. None of the participants marked this block. An open block was provided where the respondent could indicate 'Any other comment'.

Questions to determine the mother's knowledge were included and the mother simply had to indicate whether the statements were 'True' or 'False'.

Mothers could indicate on the questionnaire if they were prepared to grant the researcher an individual interview.

\section{Interviews}

Data were collected by means of in-depth interviews, during which the researcher tried to gain knowledge of and insights into the mother's world. A single question was asked: 'Tell me about your experience of breastfeeding and the management of problems during pregnancy, labour and after the birth of your baby.' The researcher conducted tape-recorded interviews until saturation of data, as demonstrated by repeating themes, occurred. Rapport was established through an attitude of honesty, openness, unconditional acceptance and respect. Six anonymous interviews were carried out until repetition of themes occurred. Communication skills included responsive listening, minimal verbal response, probing, reflecting, clarifying, summarising and silence. Comprehensive field notes were taken and analysed after the interviews to ensure that observations that were made in relation to the interviews were adequately recorded to help determine themes and categories. The interviews were added after Phase 1 of the study, where it was found that the mothers would add information on her experiences on the back of her questionnaire - the researcher accepted this as an indication of their need to elaborate on their experiences. It was hoped that this information could add depth and insight.

\section{DATA ANALYSIS}

Due to the relatively small group, data from the questionnaires were analysed by hand. The responses to each statement were analysed individually and descriptive statistics were applied by means of frequencies and percentages. The comments were analysed by the researcher and interpreted together with the results of the interviews. The results were checked by an experienced researcher.

The interviews were analysed according to the descriptive analysis suggested by Tesch (in Creswell 1994:155). Transcripts of the interviews were read to obtain an idea of the whole. Themes that emerged were clustered and coded. A co-coder, experienced in the field of qualitative research, assisted with the analysis of the transcripts of the interviews, after which a consensus discussion was held to discuss the themes and conclude the final categories. A literature control was conducted to validate the findings.

\section{ETHICAL CONSIDERATIONS}

Ethical considerations were based on the DENOSA Ethical Standards for Nurse Researchers (1998:2.3.2-2.3.4). This included obtaining informed consent from all the participants, voluntary participation, anonymity and confidentiality.

The questionnaires were distributed and collected by the organiser of the support group (in Phase 1) or the community clinic practitioner (in Phase 2) - thus the researcher was not present during data collection. All mothers received a document stating the purpose of the research and an explanation of the questionnaire, and they were made aware that they had the freedom to withdraw from the research at any time. Although written consent was not requested, participation was voluntary and only the interested persons completed the document.

Anonymity was ensured during completion of the questionnaire since these participants were not requested to add their names 
to the document, and participants willing to be interviewed wrote their telephone numbers on the document. Audio-taped recordings of interviews and transcripts were marked by means of codes and were to be kept in safe storage for two years after completion of the research. Feedback on the project was communicated to the participants via the participating clinic practitioner and during the support group sessions. The private hospitals and medical practitioners were to be provided with a copy of this article.

No harm came to the mothers or to the medical practices or private hospitals as no respondent, medical practice or hospital was indicated or identifiable on the questionnaire.

\section{RELIABILITY AND VALIDITY}

To ensure reliability and validity of the questionnaire, experts (persons holding a masters degree in midwifery and/or a diploma in community nursing) were consulted with regard to the content and formulation of questions. The evaluators of the questionnaire agreed on the adequacy of the questions investigating the topics applicable to this study, which is an indication of face validity.

The content validity of the instrument is grounded in the extensive literature triangulation, and refers to the extent to which a measure covers the range of meanings included in the concept. A wide range of questions was included, including the questioning of information regarding the recommendations to breastfeed during antenatal visits to the medical practitioner, the management of breastfeeding in the consulting room, the impact of hospital policies and practices on breastfeeding, and the breastfeeding education offered by the medical practitioner after the birth of the baby. During preliminary testing problems (mainly grammatical and editorial) in the formulation of the questions were identified and questions that appeared to be unclear were reformulated and/or language edited.

Validity was addressed by various measures. Face validity was ensured by compiling the measuring instrument in such a way that it measured the topic under investigation as accurately as possible (Babbie and Mouton 2002:122).

Reliability refers to whether a particular technique applied repeatedly to the same object would yield the same results (Babbie and Mouton 2002:119). Reliability of the questionnaire was ensured by pre-testing it for clarity and specificity on prospective respondents. The clinic practitioner was trained in the use of the instrument before distributing it to the respondents.

\section{Trustworthiness}

To ensure trustworthiness, transcripts of the interviews were analysed by the researcher, according to the descriptive analysis method (Tesch in Creswell 1994:155), and included co-coding, prolonged engagement, triangulation and adequate referencing to gain understanding of personal experiences with breastfeeding.

A literature control was conducted to compare and contrast the findings of the study. Lincoln and Guba's criteria (credibility, dependability, transferability and applicability) were used to ensure the trustworthiness of the research (Lincoln and Guba 1995:301-328). Credibility was ensured by extended exposure in the field, keeping field notes, triangulation of the data and by means of a literature control. The researcher conducted all the interviews herself. The participants determined the content as well as the direction of the interviews.

Transferability was obtained by means of a literature control, the use of purposive sampling and dense description of the data, and the use of an independent coder. Dependability included a dense description of the data and the use of an independent coder. Confirmability was achieved by carrying out an audit of the entire research process.

\section{DISCUSSION OF THE RESULTS}

\section{Biographical data}

The average maternal age of the 124 participants was 28 years, with the youngest participant being 23 years old and the oldest 40 years old.

Sixty-five percent of the participants had attended childbirth education classes and all of them were private obstetrician patients. The mothers had received antenatal care from 14 male and one female obstetrician. All the paediatricians in this study were male. Of the women, $62.5 \%$ still breastfed (however not exclusively) at six weeks post-natal.

\section{Recommendations to breastfeed: Antenatal visits to the medical practitioner}

Participants were asked to indicate all their sources of information regarding breastfeeding, including all formats. The most common source of information was the childbirth educator, who also acted as the lactation consultant. The most common format for obtaining information was a lecture, demonstration and videos. However, only $65 \%$ of the participants attended childbirth education classes.

Of the medical practitioners, $56.2 \%$ enquired on the first antenatal consultation whether the mother was planning to breastfeed. The mother's intention to breastfeed was then indicated as such in her file. None of the medical practitioners discussed infant feeding options for the first month with parents of healthy, fullterm infants in their practice. No further information regarding breastfeeding (initiation of lactation, anatomy of the breast, difference between hind milk and foremilk) was given on the subsequent antenatal visits.

One woman received information on the anatomy of the breast, initiation of breastfeeding and nipple preparation during pregnancy or while breastfeeding only when she approached the medical practitioner with a list of questions.

Of the mothers who did not attend childbirth education classes, $69 \%$ indicated that they telephoned the doctor or paediatrician first when they encountered problems. These mothers demonstrated significant deficits in knowledge regarding the benefits of and preparation for breastfeeding, and the management of common breastfeeding problems.

$31 \%$ of the mothers received written information on the topic of breastfeeding in the consulting rooms. These leaflets advertising material by companies that promote bottle-feeding as well - were not specifically handed to them but were merely displayed.

\section{The management of breastfeeding problems in the consulting rooms}

Breastfeeding questions that arise in the post-natal period are often asked via telephone communication and almost all of the respondents indicated that they received oral information from the staff in the consulting rooms when they sought help from the obstetrician or paediatrician. It was not known what this person's training in breastfeeding management was as the respondents had no knowledge of the staff's qualifications. Only one woman could discuss her breastfeeding problems telephonically with her medical practitioner after discharge - all the other participants had discussions with the receptionist.

None of the participants were referred to a lactation consultant by the staff in the consulting rooms and only one woman was referred to a lactation consultant by her medical practitioner. Of the participants who attended childbirth education classes $76.2 \%$ contacted the childbirth educator for help herself. 
Hospital policies and practices regarding breastfeeding The questions pertaining to the hospital policies and practices included the 'Steps for Successful Breastfeeding', as well as the 'Baby-Friendly Hospital Initiative'.

None of the medical practitioners or hospital staff informed the mothers of the Baby-Friendly Hospital Initiative (Box 1) or the Ten Steps to Successful Breastfeeding statements. Despite hospital claims (in advertisements) that they were baby-friendly, $85 \%$ of the participants were encouraged to provide supplemental feeds in the hospital due to 'insufficient milk supply'.

Existing hospital procedures and practices conflicted with the written breastfeeding policies and communicated the message to mothers that the health care providers expected women to bottle feed:

- $50 \%$ of the babies were fed glucose water for 'low blood sugar'.

- None of the participants were encouraged to use a cup or syringe for feeds.

- None of the medical practitioners or paediatricians recommended exclusive breastfeeding in the hospital, and assured the woman that the midwife would answer all her questions.

- None of the participants were informed by the medical and nursing staff that exclusive breastfeeding for the first four months were beneficial for the baby's health.

- None of the medical practitioners cautioned the mother against the use of some form of supplementation even when they witnessed the mother 'topping-up' and no-one encouraged more frequent breastfeeding for a perceived inadequate milk supply.

- None of the medical practitioners assisted the mothers with their breastfeeding efforts but referred them back to the midwife.

- None of the medical practitioners or paediatricians advised against the use of pacifiers until breastfeeding was well established, and all the mothers were advised by the nursing staff to use a pacifier.

- When the mother had had a Caesarean section, breastfeeding had not commenced within two to four hours postpartum in $69 \%$ of women who wanted to breastfeed.

- Rooming-in was not recommended by the medical practitioners or hospital staff at all, and all babies received an average of one bottle-feeding per night. If the mother insisted on rooming-in she was discouraged to do so by the nursing staff.

- None of the medical practitioners recommended that the infant should be fed on demand and $59 \%$ of participants indicated that either the hospital staff or the paediatrician advised them to breastfeed four hourly.

- $12 \%$ of the participants were informed by the pediatrician to start with rice cereal and boiled water between feeds, at six weeks.

- $3 \%$ of the neonates were admitted to the NICU, where breastfeeding was delayed for an average of one week. The midwives were not allowed to assist the mother in the NICU with breastfeeding attempts and all the participants felt that the NICU staff was 'too busy to help me'.

The participants in this study appeared confused with regard to breastfeeding practices: $68 \%$ indicated that the information given by the childbirth educator differed from the advice that was given in the hospital and $85.4 \%$ indicated that the information given in the hospital conflicted with the information received from books.

\section{Breastfeeding education by the medical practitioner after the birth of the baby}

Medical practitioners did not recommend that the infant be put to the breast within half an hour after delivery. However, if the mother gave vaginal birth, $62 \%$ of the participants were allowed by the attending midwife to breastfeed during the first hour after birth.
$89 \%$ of the participants indicated that the medical practitioner would enquire about their breastfeeding attempts during the ward round, but referred all questions to either the hospital staff or the paediatrician. Regardless of this fact, $69 \%$ of the participants contacted the medical practitioner's office first when problems were encountered. The receptionist, however, would then not allow the mother to speak to the doctor. Fewer than $50 \%$ of medical practitioners gave any information on the management of breastfeeding whilst the baby was receiving phototherapy. Most respondents indicated that health practitioners indicated that supplementation with formula in the first two weeks of life would not constitute problems and would not be a cause of failure to breastfeed.

All participants in this study indicated that they received information on lactation, latching, benefits of colostrum and breast milk, length of feed, stimulation of reflexes and expressing of breast milk either at the childbirth education classes or from the community clinic registered nurses after the birth of the baby.

Not once during the follow-up interviews did the participants comment negatively on the medical practitioner but the nursing staff was criticised harshly. Participants felt that the hospital midwife's knowledge and skills regarding breastfeeding was inadequate and that she underestimated the mother's interest in breastfeeding.

\section{Personal experiences with breastfeeding}

In an open-ended question, participants identified the single most valuable source of information as their childbirth educator, who taught and helped them the most with their breastfeeding efforts. However, only $65 \%$ of the participants attended childbirth education classes. The second most valuable source identified was a community clinic sister or lactation consultant, and thirdly, written material.

Only $39 \%$ of the mothers were exclusively breastfeeding their infants at six weeks. Mothers who discontinued exclusive breastfeeding were more likely to have experienced problems with their infant latching on or sucking, lack of confidence, or a perception that the milk was not sufficiently adequate to sustain the baby's needs. Health care providers furthermore recommended formula supplementation or the introduction of solids. Many mothers indicated that the medical practitioner or paediatrician advised them to stop breastfeeding if the mother had breast or nipple problems.

Participants were asked how effective they felt they were in meeting the needs of the infant. In general, 59\% felt ineffective and lacked confidence.

In this study, $10 \%$ of the participants experienced engorgement, mastitis or cracked nipples. None of them were advised to stop breastfeeding, although nursing staff were reluctant to express milk by means of a breast pump when engorgement occurred, as it 'would make more milk'. All of the participants that suffered from engorgement experienced cracked nipples and were encouraged in the hospital to use nipple shields, but without being educated on the correct application thereof. None were shown how to correct the latching difficulty that caused the problem in the first instance. These problems were subsequently corrected by the childbirth educator or community clinic sister. None of the participants were referred to a lactation consultant by the nursing staff.

\section{RESULTS OF THE PERSONAL INTERVIEWS}

The researcher conducted six interviews to determine the woman's experiences of breastfeeding. The following themes and sub-themes emerged: 


\section{Theme 1: Attitude of the hospital staff and support persons}

Sub-theme 1: The attitude of the hospital nursing staff contributed to the breastfeeding experience

The attitude of the nursing staff seemed to dominate the discussions. When the midwife was regarded as having patience, the women experienced the breastfeeding attempts positively. However, the mothers found the midwives' approach to be mostly hard-handed and impatient: 'The baby was forced, although he struggled'. The lack of support undermined the mother's confidence: 'Everything was my fault ... I was trying so hard to do everything right ... but it was my fault, my fault ... I felt insecure and didn't trust myself' and 'This (the failed attempts in the hospital) made me very resentful and ready to quit'. Five of the participants started their breastfeeding attempts with confidence, but became frustrated and anxious when they struggled or experienced problems. 'I didn't trust myself' was a repetitive statement in all of the interviews.

The sometimes personal remarks made by the nursing staff offended some of the women: 'My nipples are too small or too short; the sister said I have to make up my mind ... and said I had to stop wasting her time'. This woman stopped her breastfeeding attempts at day three in the hospital, took the prescribed medication, and re-lactated with the help of the community clinic sister after one week.

The staff were unsupportive of the women's efforts and regularly offered supplementary feeds: 'The staff was eager for us to use bottles' and '(they) .....wanted to give bottles without really helping $\mathrm{me}^{\prime}$. The mothers experienced the staff to be obstructive and unhelpful: 'Some were trained and others not ... They would undermine my attempts and sneak in bottles' and 'Even when I asked for help with latching, they would grab the baby and the boob, but gave no information'. 'The doctor said I had to start bottle-feeding as I was struggling too much with the breastfeeding'. This happened on day three before discharge. These findings correlated with the findings of Segeel and Du Plessis (2006:69) who found that the maternity staff of a particular hospital in Gauteng were unsupportive and unable to spend enough time counselling new mothers.

When a baby was admitted to the intensive care unit, bonding and breastfeeding was delayed and restricted. The NICU staff did not encourage breastfeeding and the advice given on how to express the milk was conflicting and confusing: 'They made me feel stupid to bring 5 or $10 \mathrm{ml}$ of colostrum to ICU in a syringe.' 'My doctor never gave me any advice'.

Mothers in many countries cite the advice of health care providers as the reason for their making specific infant feeding decisions (Sharret-Stevens 2002:1). Unfortunately, advice from health care providers is too often uninformed, undermining efforts to support mothers who elect to breastfeed. Breastfeeding is both an art and a skill, and the capability of a midwife to deal with breastfeeding concerns may be increased by experience. However, relying on personal experience as the primary source of information narrows the scope of assistance that is available to the mother (Hellings \& Howe 2000:268).

\section{Sub-theme 2: Conflicting advice offered by hospital staff}

A repeating theme was the conflicting advice given by nursing staff of both the maternity section as well as the NICUs. The staff did not follow or implement their own hospital's policies, and the advice given was inconsistent and did not reflect what the mothers had read in books. The conflicting advice given by the nursing staff made the women feel insecure and unsuccessful even when the baby was progressing well. The women resented the pressure to feed only four-hourly and did not experience any form of demand feeding principles. 'I thought she was starving' and 'It seemed all wrong!' was mentioned by all participants, and they wanted concrete quantitative information with regard to the frequency and duration of breastfeeding.

A successful breastfeeding promotion programme depends in part on the support of the staff involved both directly and indirectly in its administration (Hellings \& Howe 2000:268). Not once during these interviews did the participants comment negatively on the medical practitioner, although twice it was mentioned that the medical practitioner did not offer any advice at all during the hospital stay. Rubin (2008:17) is of the opinion that the doctor or paediatrician's knowledge and skills regarding breastfeeding is essential for breastfeeding success.

\section{Sub-theme 3: Attitudes of the support persons}

When the woman had good support in the form of a community nurse, childbirth educator or husband, her breastfeeding experiences were good, even if she initially struggled with latching difficulties or engorgement. This support influenced her positively and instilled confidence: 'I was lacking confidence and really did not feel strong or secure, but because I had a lot of positive support, I was successful'. Rubin (2008:13) is of the opinion that the mother should create her own breastfeeding affirmation for a positive breastfeeding mindset and that she should surround herself with allies that will support her.

The husband or partner's attitude was particularly important to the new mother and if he was unsupportive then her breastfeeding experience was negative. This then strained their relationship, and in turn affected the breastfeeding attempts negatively (Odendaal 2003:103). This is reflected in the following statements: 'He didn't attend antenatal classes and then HE tells me I'm doing it wrong' or 'He didn't trust me!' Segeel and Du Plessis (2006:71) found that the support given by the partner or spouse was instrumental in her success with breastfeeding. The women expressed appreciation when the partners were supportive and disappointment when they were not.

\section{Theme 2: The mothers doubted their own abilities and needed reassurance}

Many mothers have the perception that breastfeeding is easy and natural and expect breastfeeding to be romantic, wonderful and natural - which is far removed from the reality. The participants in this study lacked confidence and felt insecure because they did not anticipate problems or difficulties. When the mother experienced problems with breastfeeding she experienced feelings of intense sadness and failure. These feelings culminated in anger. The mothers all needed reassurance and confirmation from the nursing staff and health care providers. Rubin (2008:4) argues that a mother's conscious and subconscious attitude about breastfeeding will profoundly affect her future breastfeeding relationship - she should trust her own abilities and recognise her own personal feelings about breastfeeding before her baby is born (Pessl 2006:1-8).

\section{CONCLUSIONS AND RECOMMENDATIONS}

As a direct result of social and economic change, urbanisation and the marketing of breast milk substitutes, the initiation and duration of breastfeeding declined worldwide in the twentieth century. Over the past two decades, however, breastfeeding initiation and duration has begun to increase in many developing countries. In South Africa, the Department of Health's recommendation for exclusive breastfeeding is based on abundant data, including studies conducted within the PanAfrican context, that indicates profound benefits of breastfeeding for infants and mothers. In order to render quality post-natal care, hospitals should implement the Baby-Friendly-Hospital Initiative (UNICEF 2007)

In this study it was found that medical practitioners are, at best, neutral about optimal infant nutrition. Women place a high 
value on the advice of the health care provider, yet this study revealed that medical practitioners in private practices do not support, educate or inform mothers on breastfeeding at all, and they do not engage in breastfeeding education while the mother is still in the hospital. This could reflect a lack of interest or knowledge. It is essential that all medical practitioners who interact with pregnant or breastfeeding women have sufficient knowledge both to help women make informed infant feeding decisions and to manage common breastfeeding problems. To be consistent with national health goals, breastfeeding should be encouraged whenever possible when providing antenatal care. Routine health services offer opportunities to provide support for optimal feeding practices for newborns and women need to be adequately counselled on breastfeeding and breastfeeding practices during pregnancy.

Based on the results of this study, it is evident that breastfeeding attitudes and hospital management issues have not changed substantially from earlier studies. Exclusive breastfeeding rates are low, health practitioners are unfamiliar with the contents of the Baby-Friendly-Hospital Initiative and hospitals do not comply with the Ten Steps. Early breastfeeding within the first hour of birth is not the norm. Of great concern is the implied perception that breastfeeding and formula feeding are equally acceptable methods for feeding infants.

Nursing practitioners place a high value on health promotion and teaching in their practices, and the ability to promote and support breastfeeding may be one of the most beneficial activities they can perform because breast milk is widely acknowledged as the best nutrition for the human infant. However, the results of this study indicate a lack of awareness of the benefits of optimal practices, inadequate health worker training on optimal practices and counselling skills. Experience may somewhat increase the capability of a medical practitioner or midwife to deal with breastfeeding concerns, although there remains a strong need for basic education in the art and science of breastfeeding. There is information to be obtained that experience alone does not provide. In fact, relying on personal experience as the primary source of information may narrow the focus of assistance that is made available to patients or may limit the strategies to solve problems that the clinician did not experience.

According to Myburgh (2003:176), an important prerequisite for successful breastfeeding should be the training of all health care providers in the technique of breastfeeding and lactation, the expressing of breast milk and management of problems in a scientific manner. Breastfeeding has been neglected in pre-service and in-service training of most health care workers, leaving a serious gap in their knowledge and skills (WHO 2005:10). UNICEF and WHO place major emphasis on training health care workers in the fundamentals of lactation and breastfeeding counselling.

Information, support and confidence building contribute to the establishment and maintenance of optimal breastfeeding practices. Enthusiastic support and knowledgeable guidance will increase breastfeeding initiation and duration. Therefore, educational programmes should be targeted to health care professionals.

Many women have limited contact with health services or welltrained health professionals after childbirth. Strengthening community-based activities to increase skilled and timely support for breastfeeding is essential. This includes education support from skilled birth attendants and existing community groups, as well as referral to support groups or lactation consultants. Community-based approaches to breastfeeding are unlikely to succeed or to be sustained without the involvement of the medical practitioner.

\section{Recommendations for further research}

While significant progress has been made globally to promote and support breastfeeding practices, a comprehensive breastfeeding programme should be formulated in South Africa.

Although national statistics are not available, it appears that the initiation and maintenance of exclusive breastfeeding is low in South Africa. A national survey should be compiled on breastfeeding practices in both rural and urban areas.

The generalisation of the findings of this research study is restricted by the sample size.

Physician support for breastfeeding mothers has been shown to improve breastfeeding rates, but no evaluation of the adequacy of physicians' breastfeeding related training has been conducted. There is furthermore a limited body of literature pertaining to the knowledge and attitudes of medical practitioners towards breastfeeding. Given the health value of breastfeeding for both the mother and baby, it is important to assess the knowledge, experience and attitudes that these professionals bring to the care setting. Aspects that should be included in health education regarding breastfeeding are the advantages and disadvantages, production of breast milk as well as expressing, and the management of common breastfeeding problems.

\section{REFERENCES}

Babbie, E. \& Mouton, J., 2002, The practice of social research, Oxford University Press, Cape Town.

Bhutta, Z.A., Darmstadt, G.L., Hasan, B.G. \& Haws, R.A., 2005, 'Community based interventions for improving perinatal and neonatal health outcomes in developing countries: A review of the evidence', Pediatrics 115(suppl. 2), 519-617.

Cresswell, I.W., 1994, Research design: Quantitative and qualitative approaches, Sage, London.

DENOSA, 1998, Ethical standards for the nurse researcher, Denosa, Pretoria.

Du Plessis, D.W., 1992, 'Vroue se belewenis van vaginale geboorte', Ongepubliseerde magister-skripsie, Rand Afrikaans Universiteit.

Du Plessis, D.W., 2002, 'Die inligting wat die mediese praktisyn aan moeders gee rakende borsvoeding', Ongepubliseerde opname, Rand Afrikaans Universiteit.

Fraser, D.M., Cooper, M.A., Nolte, A.G.W., 2006, Myles Textbook for Midwives. African Edition, Churchill Livingstone Elsevier, London.

Freed, G.L., Clark, S.J., Sorenson, J.R., Lohr, J.A., Cefalo, R. \& Curtis, P., 1995, 'National assessment of physicians' breastfeeding knowledge, attitudes, training, and experience', Journal of the American Medical Association 273(6), 472-476.

Hayes, B., 1981, 'Inconsistencies among nurses in breastfeeding knowledge and counselling', Journal of Obstetric, Gynecologic and Neonatal Nursing 10(6), 430-433.

Hellings, P. \& Howe, C., 2000, 'Assessment of breastfeeding knowledge of nurse practitioners \& nurse midwives', Journal of Midwifery \& Women's Health 45(3), 264-270.

Hillenbrand, K.M. \& Larsen, P.G., 2002, 'Effect of an educational intervention about breastfeeding on the knowledge, confidence, and behaviors of pediatric physicians', Pediatrics 110(5), e59.

Howard, C.R., Schaffer, S.J. \& Lawrence, R.A., 1997, 'Attitudes, practices, and recommendations by obstetricians about infant feeding', Birth (24)4.

Kieffer, E.C., Novotny, R. Welch, K.B., Mor, J.M. \& Thiele, M., 1997, 'Health practitioners should consider parity when counselling mothers on decisions about infant feeding methods', Journal of the American Dietetic Association 97(11), 1313-1116.

Kitzinger, S., 2000, Rediscovering birth, Little Brown, London.

Lincoln, Y.S. \& Guba, E.G., 1995, Naturalistic inquiry, Sage, Newbury Park. 
Myburgh, M., 2003, 'Die faktore wat die MIV-positiewe moeder se baba voedingsbesluit beinvloed: 'n Verkennende studie', Ongepubliseerde PhD-proefskrif, Universiteit van die Vrystaat.

Odendaal, V., 2003, 'Indikatore vir post-partum depressie', Ongepubliseerde Mcur-skripsie, Rand Afrikaans Universiteit.

Pessl, M., 2006, Exclusive breastfeeding: Does it matter?, paper presented to the ICM 27th Triennial Conference, Glasgow, Scotland, 4th June.

Rubin, S.H., 2008, The ABCs of breastfeeding, AMACOM Publishers, New York.

Ryan, A.S., 1997, 'The resurgence of breastfeeding in the United States', Pediatrics 99(4), e12.

Schanler, R.J., O'Connor, K.G. \& Lawrence, R.A., 1999, 'Pediatricians' practices and attitudes regarding breastfeeding promotion', Pediatrics 103(3), e35.

Segeel, I.R. \& Du Plessis, D.W., 2006, 'The childbirth and breastfeeding experiences of primigravida who attended childbirth education classes', Health SA Gesondheid 11(2), 62-74.

Sharret-Stevens, B., 2002, 'Breastfeeding and healthcare professionals: A review of knowledge, attitudes and experience towards breastfeeding', International Journal of Childbirth Education 10, 4-5.
Taveras, E.M., Lii, R., Grummer-Strawn L., Richardson, M., Marshall, R., Rego, V.H., Miroshnik, I. \& Lieu, T.A., 2004, 'Opinions and practices of clinicians associated with continuation of exclusive breastfeeding', Pediatrics 113(4), e283-e290.

UNICEF, 2007, 'The Baby-Friendly-Hospital Initiative 2006', viewed 10 September 2007, from www.unicef. org/programme/breastfeeding/baby.htm (Accessed 10 September 2007).

WHO, 2003, Community based strategies for breastfeeding promotion and support in developing countries, WHO Department of Child and Adolescent Health and Development, Geneva.

WHO, 2005, Policy brief one: Integrating maternal, newborn and child health programmes. World Health Report 2005: Make every mother and child count, WHO, Geneva.

WHO/UNICEF, 2003, The global strategy for infant and young child feeding, WHO, Geneva.

WHO/UNICEF, 2006, Opportunities for Africa's Newborn, WHO, Geneva.

WHO, UNICEF, UNFPA, UNAIDS, 2003, HIV and infant feeding: Guidelines for decision-makers, WHO document WHO/NUT/ CHD/98.1, WHO, Geneva. 